\title{
A Study on Gender Involvement in Environmental Protection in Pedro Village, Lagos
}

\author{
Chukwu, M. N. \\ School of Science and Technology, National Open University of Nigeria, Lagos-Nigeria
}

\author{
Doi:10.5901/ajis.2014.v3n7p20
}

\begin{abstract}
Women around the world play distinct roles in protecting the environment; plants and animals in forests, dry lands, wetlands and in agriculture. This study examined women involvement in environmental protection in Pedro village, a rural riverine area in Iwaya-Yaba, Lagos. A total of 120 women dwelling in Pedro village, Lagos were used for the study. Primary data were generated from a structured questionnaire survey of the women. Focus group discussion and participatory observations were also used as basic data gathering tools. Data collected were summarized and computed using descriptive statistics (frequency and percentages). Results of this study showed that women have some knowledge in protecting the environment and natural resources. They participated in environmental protection significantly through agricultural activities, drainage management, waste disposal, flood management and water resource management. It was recommended that enlightenment campaigns, workshops and seminars should be organized on regular basis to educate the women and the general public on the importance of and how to improve on environmental protection. Women should also be encouraged to be part of any committee on environmental protection projects, programmes, and policies to address gender imbalances in decision making.
\end{abstract}

Keywords: gender, environment, protection, natural resources, programmes.

\section{Introduction}

Environmental protection is a practice of protecting the natural environment on individual, organizational or governmental levels, for the benefit of the natural environment and humans (Harding, 2006). The awareness of resource depletion, degradation of natural systems and dangers of polluting substances has greatly increased in the past decade. These ugly conditions are destroying fragile ecosystems and displacing communities, especially women from productive activities and increasing the threat to a safe and healthy environment (Tondi, 2001). Attention has been paid on gender sensitivity in the field of environmental protection. A more common view is that more women than men have a positive attitude towards environmental issues. Francoise d'Eaubonne in 1974 first proposed eco-feminism, describing the women potential impact on the environment and pointing out that women should take a more active role in environmental protection (Brent, 1996).According to World Bank 1992, "Women play an essential role in the management of natural resources including soil, water, forest and energy. They often have a profound traditional and contemporary knowledge of the natural world around them". Gender environmental relations have valuable ramifications in regard to the understanding of nature between men and women, the management and distribution of resources and responsibilities and the day to day life and well-being of people (Nightingale, 2002). Women's perspective and values for the environment are different from men's. Women give greater priority to protection of and improving the capacity of nature, maintaining farmlands and caring for the environment's future (Dixon, 1989).

Studies have shown that women have a stake in the environment which is reflected in the degree to which they care for natural resources. In the third world countries, women are seen as the primary users of natural resources. Rural women of Ghana are particularly dependent on the environment for their livelihood because their predominant occupation is agriculture, and it is their responsibility to provide food and water for their families. Rural women also depend on wood fuel for commercial use. For this reason, their role in the conservation of our environment is crucial (Shanley, Da Silva and Macdonald, 2011).Women's direct contact with environment has produced their deep- knowledge about the environment, thus, women have served as agriculturalists, water resources managers, and traditional scientists, among others. Women are not only knowledgeable about the environment; they are also protective and caring (Akwa, Marcus and Rahman, 2008). Ecofeminism refers to women's and feminist's perspectives on the environment where the domination and exploitation of women, of poorly resourced people and of nature are at the heart of the ecofeminist movement (Boserup, 1970). One of the biggest movements in the history of women and environment is the Green Belt movement founded by Wangari Maathai in Kenya on the environmental day in 1977. This was one of the first efforts to 
incorporate the link between gender and environmental resources within grassroots; in this case by mobilizing women to plant indigenous trees. A few women started by planting some trees in Maathai's backyard. As at 2005, 30 million trees had been planted by participants in public and private lands. This movement was designed to combat creeping desertification, restore soil health and protect water catchment areas (Cuomo, 2001).

Governments are now seeing a number of environmental problems; climate change, ozone depletion, dumping of hazardous wastes, destruction of biological resources and the impact of desertification (Tolba, 1992). The need to protect the environment hence becomes imperative. There is also the need to understand the various ways women have actively participated in environmental protection with a view to integrate them into environmental protection programmes. The objective of this paper is to examine gender involvement in environmental protection, with special reference to Pedro village, Lagos.

\section{Methodology}

\subsection{Population and Sample}

The sample population for the study comprised of 120 women out of a population of 1,244 women dwelling in Pedro village, Lagos. Stratified sampling technique was used to select the women from the study area. The entire population was first divided into six subgroups and then twenty were randomly selected from each subgroup. This comprises women that had participated in environmental protection programmes and those presently involved in environmental protection programmes.

\subsection{Instrument of the study}

Focus group discussion, participatory observations and interview with a structured questionnaire titled "Women and Environmental Protection" were the instruments used to ascertain the environmental protection activities of the sample. The questionnaire was developed by the researcher. The instrument comprised of two sections. Section A focused on the demographic information on the respondents. Section B had 20 Likert type items and was designed to assess women participation in environmental protection. This included functions aimed to indicate (SD); Strongly Disagree, (D); Disagree, (U); Undecided, (A); Agree, (SA); Strongly Agree. The questionnaire was administered by the researcher in August, 2013 to the respondents. The respondents were personally approached and briefed about the purpose as well as the significance of the study by the researcher. Those who were chanced filled the questionnaires and returned immediately while the researcher visited the next day to collect from the others.

\subsection{Validation and Reliability of Instrument}

The instrument for the data collection was validated by experts in Environmental Sciences. Modifications were made and a few inadequate items were removed from the questionnaire. Their comments were used to improve the quality and content validity of the instrument before administration. The test-reset reliability scale yielded reliability coefficient of 0.83 . The instrument was thus considered valid and reliable to be used for assessment of gender involvement in environmental protection.

\subsection{Analysis of Results}

Data collected were summarized and computed using descriptive statistics (frequency and percentages).

\section{Results and Discussion}

Table 1, showed the age and marital status of the women in the sample. Majority of the women (38\%) are in their middle ages (30-39 years). This showed that most of the women are still in their prime ages and hence can participate actively in environmental protection activities. Majority of the women (74\%) are married. This high proportion of married women in the study area suggested that they are likely to be more environmentally aware since they are home keepers. 


\subsection{Women's participation in environmental protection}

From Figure 1and Table 2, 60\% of the women were cleaning their environment on daily basis, $34 \%$ were involved in weekly cleaning while only $4 \%$ clean their environment occasionally.

Table 1:Age and Marital Status of the Surveyed Women $(\mathrm{N}=120)$

\begin{tabular}{|c|c|c|}
\hline Variables & & Frequency Percentage (\%) \\
\hline & Less than 20 years & 0605 \\
Age & $20-29$ years & 3025 \\
& $30-39$ years & 4638 \\
& $40-49$ years & 2118 \\
& 50 years and above & 1714 \\
\hline Marital status & Single & 3126 \\
& Married & 8974 \\
\hline
\end{tabular}

Source: Researcher's field survey.

Table 2:Women involvement in Environmental protection programmes ( $N=120)$

\begin{tabular}{|l|c|c|}
\hline Variables & & Frequency Percentage (\%) \\
\hline \multirow{2}{*}{ Cleaning of the Environment } & Daily & 7260 \\
& Weekly & 4134 \\
& Occasionally & 0706 \\
\hline \multirow{2}{*}{ Involvement in agriculture } & Yes & 8268 \\
\hline \multirow{2}{*}{ Waste disposal } & No & 3832 \\
\hline \multirow{2}{*}{ Flood management } & Yes & 7058 \\
& No & 5042 \\
\hline \multirow{2}{*}{ Drainage management } & Yes & 7764 \\
& No & 4336 \\
\hline \multirow{2}{*}{ Water Resources Management } & Yes & 9680 \\
& No & 2420 \\
\hline
\end{tabular}

Source: Researcher's field survey.

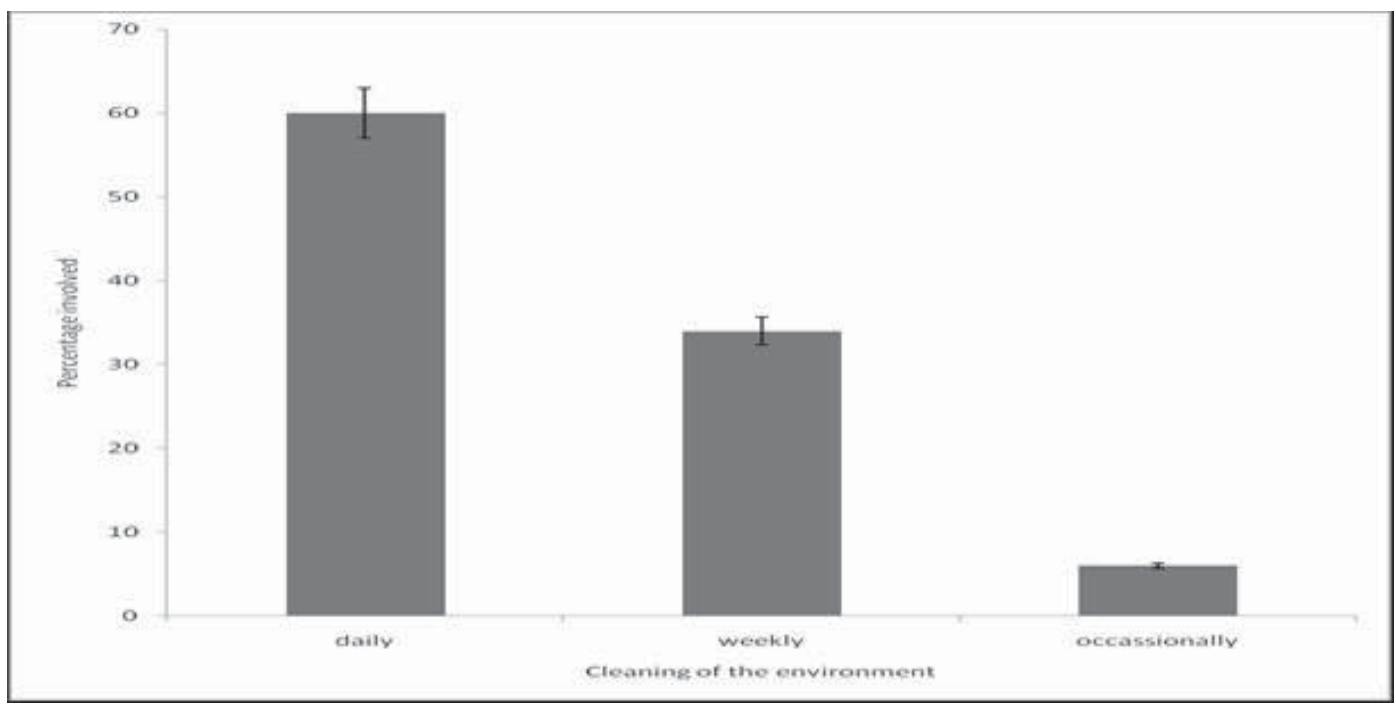

Figure 1: Frequency of cleaning the environment. Values shown are Mean $\pm \mathrm{SE}$. 


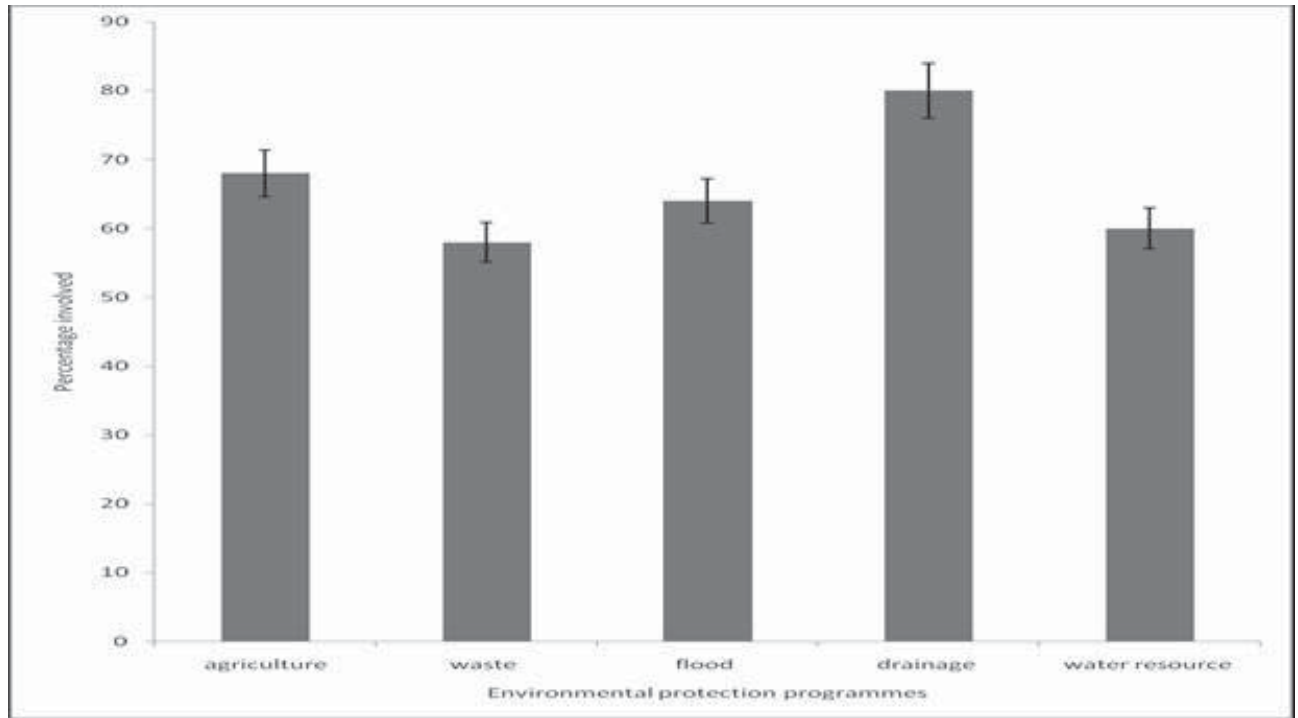

Figure 2:Women participation in Environmental protection programmes. Values shown are Mean $\pm \mathrm{SE}$.

It was discovered that most of the women in Pedro village have some knowledge of environmental protection. They participated in environmental protection in the following ways.

\subsection{Women in Agriculture}

In Pedro village, $68 \%$ of the women were actively involved in agricultural activities; crop and fish farming (Table 2 and Figure 2). They produce more than half of the crops that were grown. According to the information obtained from the discussion and individual interview, women's roles in agriculture include clearing of the land, hoeing, planting, and weeding. They were also involved in crop and fish harvesting, storage and marketing of the agricultural products.

\subsection{Waste disposal}

Proper waste disposal is an indication that environmental health is essential to prevent diseases. In the light of this, it was observed that women (58\%) took a leading role in preventive measures against environmentally transmitted diseases and water borne diseases (Table 2 and Figure 2). They did this by ensuring proper disposal of refuse always keeping their homes and surroundings clean with the help of the youths. They also have a women body that acts as watch dog in collaboration with the youths against dumping of refuse and toxic waste along their community coast.

\subsection{Women in flood management}

Personal observation and interviews held with the respondents revealed that most of the women (64\%) play a significant role in flood management (Table 2 and Figure 2). Pedro village being a riverine area, there is high incidence of flooding there. During the rainy season, the houses get waterlogged and streets are flooded. The women engage themselves in preventive measure such as using sand bags to barricade some vital locations against flooding, digging of gutters for channeling flood away from their residents to large ditches which they later use as fish ponds.

\subsection{Drainage management}

In the course of personal participatory observation, it was observed that majority of the women (80\%) participated actively in keeping the drainages around them clean (Table 2 and Figure 2). The women clean the drainages on a regular basis and fine those who fail to participate in such an exercise. According to some respondents, it is a taboo for men to engage in such. This is in agreement with the findings of Shanley et al (2011) that there is evidence that women are more environmentally aware and engage more in environmental protection activities such as recycling, reuse and 
environmentally conscious shopping.

\subsection{Water Resources Management}

Women are always at the center of the management of water resources both at communal and household levels. They are in charge of the control and management of communal taps; preventing children from damaging the water pipes. The burden of fetching water for cooking and other home use falls on the women and girls. They make use of streams, pond, wells, rivers water when the tap water is not available. In addition, they take care of these water bodies to avoid water pollution which will be detrimental to aquatic lives.

\section{Conclusion}

The main focus of this study was to examine gender involvement in environmental protection using Pedro village, IwayaYaba, Lagos as study area. Results showed that the women significantly participate in environmental protection through agricultural activities, drainage management, waste disposal, flood management and water resource management.

\section{Recommendations}

To enhance gender involvement in environmental protection, the following recommendations were made;

i. Enlightenment campaigns, workshops and seminars should be organized on regular basis by the government and non-governmental organizations to educate the women and the general public on the importance and how to improve on environmental protection.

ii. Women should be encouraged to be part of the committees on environmental protection projects, programmes, and policies to address gender imbalances in decision making.

iii. Our drainage systems should be put in good conditions

\section{References}

Akwa, L., Marcus, N. D. and Rahman, S. A. (2008). Analysis of Fuel Wood Utilization Among Rural Women In Akwanga Area of Nasarawa State, Nigeria. The Abuja Journal of Geography and Development.Vol. 1, No. 2.

Boserup, E. (1970). Women's role in Economic Development. George Allen and Unpin Ltd., London.

Brent, S. (1996). Thinking Globally and Acting Locally: Environmental Attitude, Behavior and Activism Journal of Environmental Management 4,27.

Cuomo, C. J. (2001). Ecological Feminism: An Ethic of Flourishing. Routledge, London.

Dixon, M. R. (1989). Women's Work in Third World Agriculture: Concepts and Indicators. Women, Work and Development Series, No. 9.Genava.ILO.

Harding, R. (2006). Ecological sustainability development: origins, Implementation and Challenges. Desalinations 187 (3),229-29.

Nightingale, A. J. (2002). Participating or just sitting in? The dynamics of gender and caste in community forestry.Journal of forestry and livelihood 2,17-24.

Shanley, P., Da Silva, F. C. and Macdonald, T. (2011). Brazil's social movement, women and Forests: A case study from the National Council of Rubber tappers. International Forestry Review 13, 233-244.

Tolba, M. (1992). UNEP, Changes for Past Two Decades and the Prospects for the Future. UNEP, Our planet Vol. 4, No. 6, Pp.8-11.

Tondi, T. (2001). Women, environment and development: Sub-Saharan Africa and Latin America. Thesis and Dissertation.Paper 1549. http://scholar commons.usf.edu/etd/1549.

World Bank (1992).Development and Environment. World Development Report.New York, Oxford University Press. 